\title{
Effect of seeding times, foliar treatments (with salicylic acid, humic acid and high phosphorus fertilizer) and their interaction on mung bean (Vignaradiata L. Wilczek) yield
}

\author{
Ali HusainJasim and Nagham A. Muhsen*1 \\ Prof. Dr. and MSc student, Agric. Coll. , Babylon University, Iraq
}

\begin{abstract}
The experiment was conductedina field Crop Science Department in AbuGharaq/Hella/Babylon provinceduring 2013to study the effectof foursowing dates(15/5, 15/6, 15/7 and 15/8), five spraying treatments(salicylic acid0.5 and $0.1 \mathrm{mM}$, humicacid, highphosphorus fertilizer, in addition to control)and their interaction on yield of mung bean plants. Randomized complete block design under split plot arrangement in triplicate was used. Plants were sprayed twice (after 30and 45 daysof seeding) and therequired measurementswere analyzedandthe results showed that: Second time of seeding was superior in the number of pods.plant ${ }^{-1}, 100$ seeds weight, seed protein content and seed yield. Forth seeding time was superior in pod seed number and pod length. High phosphate fertilizer was superior in the number of pods.plant ${ }^{-1}$, pod seed number, pod length, protein percentage and seed yield. Humic acid was superior in 100 seeds weight. The interaction of high phosphate in second seeding was superior in the number of pods.plant ${ }^{-1}, 100$ seeds weight and seed yield.
\end{abstract}

Key words:foliar fertilizer, mung bean, seeding time, salicylic acid, humic acid,

\section{Introduction}

Mungbean(Vignaradiata L. Wilczek)is one of the most important pulse crops for protein supplement in subtropical zones of the world. It is widely grown as a short duration catch crop between two principal crops. it contains $51 \%$ carbohydrate, $24-26 \%$ protein, $4 \%$ mineral, and $3 \%$ vitamins [1]. In order to increase the productivity ofthis crop, ithas become necessary tostudyits requirementsfor growthand production. Seeding date is animportant factorsaffecting growth and yield traitswhichvary depending onthe environmental conditionsassociated with theappointmentof agriculture, particularly temperature, light and humidity,whichdeterminesthe best timefor mungbean cultivation. Growth is affectednegatively or positivelybyplant growthregulators includingsalicylic acidwhich works toimprove the productivity ofcropthroughits effect on theimportant physiologicalprocess inthe plantsuch as growth, photosynthesis,flowering anddrought resistance[2].Thenutrientsis no less importantforgrowth regulatorsandthe plants need it in variousstages of growth, if it is added to thesoilorsprayedon the plant. The most importantof thesenutrientsare nitrogen, phosphorus, potassium,humic substances. Phosphorusisneeded byplantsin large quantitiesand playsan important rolein the life ofthe plantas itenters in the compositionof manyimportant organic compoundsin the biological process. Humic substancesplay a key roleinsoil fertility andplant nutrition, and thathumichad a direct impact onplant growth[3], andindirect effectsthrough the improvement ofsoil propertiessuch asventilation, permeability and water holding capacity[4] . Because of the lack ofstudieson this topic, wehave proposedthis study todetermine the effect ofplanting datesand spraying stimuli compounds on growth andyieldofmungbean.

\section{Materialsandmethods}

The experimentwas conductedin the province ofBabylon/Hilla/Abo-gharaq (10 km west of Hilla city)at 2013according tosplit plot design with arrangement of randomizedblock design. Planting datesrepresented withinthe main plotsand the spraying treatments(salicylic acid 0.5 and $1 \mathrm{mM}$, humicacid, highphosphorusand control)within subplots, with threereplicates. Theexperimental unitareawas $6 \mathrm{~m}^{2}(3 \mathrm{~m} \times 2 \mathrm{~m})$. Table (1)shows somechemical and physical characteristicsof the soilbefore plantingand at theend of the experiment.After plowedanddivided the soil , local mungbean seeds were seeding at the datesof $(15 / 5,15 / 6,15 / 7$ and 15/8), in lines ( $150 \mathrm{~cm}$ length an 50cmbetween ) at the quantity ofseed5g perline. NPK (18-18-18)Fertilizer at 200 $\mathrm{kg} / \mathrm{ha}$ with $100 \mathrm{~kg} / \mathrm{ha}$ urea was used before seedingandmixed with the soil. Spraying treatments was done twice (after 30 and 45days from sowing). Tenplantsper experimental unit were selected randomlyto determine pods number.Plant ${ }^{-1}$, the average length ofpod(cm), number of seeds.pod ${ }^{-1}, 100$ seed weight. Dry seed yield was

$*^{1}$ Part of M. Sci. thesis of the second author 
calculated from the fourth internalline of eachexperimental unitanditwas attributed tohectare. The results were analyzedstatistically, and the average had beencompared according to thelesssignificant difference(LSD)atprobability of $0.05 \%$.

Table (1)some chemicaland physicalcharacteristicsof the soil

\begin{tabular}{|l|l|l|l|}
\hline \multicolumn{3}{|l|}{ Before sowing } & After harvesting \\
\hline $\mathrm{EC}\left(\mathrm{dS} . \mathrm{m}^{-1}\right)$ & 1.2 & 1.0 \\
\hline $\mathrm{pH}$ & 7.8 & 7.0 \\
\hline \multicolumn{5}{|l|}{} \\
\hline Soil texture & sand & silt & clay \\
\hline Silty loam & 336 & 518 & 146 \\
\hline
\end{tabular}

III. Results and Discussion

Table (2) showed that thesecond date 15/6 was superior upon the rest other dates in increasing pods number.plant ${ }^{-1}$ whichreached14.8 with a percentage increase of $20.3 \%$ compared tothe firstdate, which gave aloweraveragenumberofpods12.3. There were no differences between the third and fourthdates ,but they were significant superiorityuponthe first date. It is notedfrom the tablethat allspraying treatments led to a significant increase in pods number.plant ${ }^{-1}$ comparedto control,andsprayinghighphosphorusfertilizer was superior compared to other spraying, which gave 15.7 with a percentage increase of $36.5 \%$ compared tocontrolthat gavethe lowest valueof 11.5 . The interaction betweentreatments had asignificant effectand thetreatment of highphosphorusfertilizer at second date(15/6)was superior by giving 16.3pod.plant ${ }^{-1}$, whilethe lowest numberresultedfrom controlinthe first date $(15 / 5)$ which gave 9.3 .

Table (2): Effect ofplanting datesand,somestimuli and their interaction in the number ofpods.plant ${ }^{-1}$

\begin{tabular}{|c|c|c|c|c|c|c|}
\hline & B & SA $0.5 \mathrm{mM}$ & SA $1 \mathrm{mM}$ & Humic acid & High P fert. & average \\
\hline $15 / 5$ & 9.3 & 12.4 & 11.4 & 13.9 & 14.5 & 12.3 \\
\hline $15 / 6$ & 13.1 & 14.2 & 14.5 & 15.8 & 16.3 & 14.8 \\
\hline $15 / 7$ & 11.1 & 13.3 & 12.7 & 14.7 & 15.5 & 13.5 \\
\hline $15 / 8$ & 12.6 & 13.6 & 13.4 & 15.5 & 15.6 & 14.1 \\
\hline average & 11.5 & 13.4 & 13.0 & 15.0 & 15.7 & \\
\hline LSD $_{0.05}$ & \multicolumn{6}{|l|}{$\mathrm{A}=0.5743 \mathrm{~B}=0.6102 \mathrm{AB}=1.1843$} \\
\hline
\end{tabular}

Table (3) shows that fourth date was outweigh compared tofirst and thirddate in thenumber of seeds. $\operatorname{pod}^{-1}\left(9.1\right.$ seeds.pod $\left.^{-1}\right)$ withan increase percentage of9.6\%compared tothe firstdate, which gave the lowest $\left(8.3\right.$ seeds. $\left.\operatorname{pod}^{-1}\right)$. It is notedfrom the table, there weresignificant differencesbetween thespraying treatments, as itsurpassedtreatments ofhighphosphorusfertilizer andhumussignificantly on the rest otherspraying, which gave an average number of seeds9.3and 9.1 seeds.pod ${ }^{-1}$ with an increase percentage of 12.0 and $9.6 \%$, respectively, compared tocontrol treatment.The interactionbetweentreatmentshad a significant effect and sprayinghigh-phosphorus fertilizerat fourthdate $15 / 8$ was superior on mostinteractions, which gave 9.8 seed.pod $^{-}$ ${ }^{1}$,whilecontrol treatments at thirddate gave the fewest 8.1 .

Table (3): The effect ofplanting dates, some stimuli spraying and their interactions on seeds number.pod ${ }^{-1}$

\begin{tabular}{|c|c|c|c|c|c|c|}
\hline A & control & SA $0.5 \mathrm{mM}$ & SA $1 \mathrm{mM}$ & Humic acid & High P fert. & average \\
\hline $15 / 5$ & 8.5 & 7.7 & 8.5 & 8.4 & 8.4 & 8.3 \\
\hline $15 / 6$ & 8.2 & 8.9 & 8.4 & 9.5 & 9.6 & 8.9 \\
\hline $15 / 7$ & 8.1 & 8.6 & 8.4 & 9.2 & 9.3 & 8.7 \\
\hline $15 / 8$ & 8.3 & 8.8 & 9.0 & 9.4 & 9.8 & 9.1 \\
\hline average & 8.3 & 8.5 & 8.6 & 9.1 & 9.3 & \\
\hline LSD $_{0.05}$ & \multicolumn{7}{|l|}{$\mathrm{A}=0.1618 \quad \mathrm{~B}=0.2239 \mathrm{AB}=0.4203$} \\
\hline
\end{tabular}

Notesfrom table(4) showed that fourth date $15 / 8$ was superior on the rest other seeding datesinthe average of pod length $(7.70 \mathrm{~cm})$ with percentage increase of $12.6 \%$ compared tothe first datewhich gaveless length $(6.84 \mathrm{~cm})$. There were no differences between second andthird date,butthey were superiorcompared tothe first date. There were asignificant differencesbetween sprayingtreatments and the treatments of sprayinghighphosphorusfertilizer andhumuswere superior significantly compared to the other, which gave 7.38 and $7.31 \mathrm{~cm}$, respectively, with a percentage increase of $4.6 \%$ and $3.7 \%$ compared to control treatment.Theinteractionbetween thetreatments had significant effect, whichsprayinghigh-phosphorus fertilizerat fourth date (15/8) was superior uponthe rest interactionsandgave an average length of $8.16 \mathrm{~cm}$, while theshorterpod length $(6.1 \mathrm{~cm})$ resulted from control treatmentat first date. 
Table (4)effect ofplanting dates, some stimuli spraying and their interactions on pod length $(\mathrm{cm})$

\begin{tabular}{|c|c|c|c|c|c|c|}
\hline A B & control & SA $0.5 \mathrm{mM}$ & SA $1 \mathrm{mM}$ & Humic acid & High P fert. & average \\
\hline $15 / 5$ & 6.10 & 6.51 & 7.23 & 6.71 & 7.64 & 6.84 \\
\hline $15 / 6$ & 6.75 & 6.70 & 7.23 & 7.47 & 7.15 & 7.06 \\
\hline $15 / 7$ & 7.54 & 7.45 & 6.86 & 7.23 & 6.58 & 7.13 \\
\hline $15 / 8$ & 7.80 & 7.49 & 7.24 & 7.83 & 8.16 & 7.70 \\
\hline average & 7.05 & 7.04 & 7.14 & 7.31 & 7.38 & \\
\hline LSD $_{0.05}$ & \multicolumn{7}{|l|}{$\mathrm{A}=0.1154 \mathrm{~B}=0.1275 \mathrm{AB}=0.2460$} \\
\hline
\end{tabular}

Table (5) showed that second date $15 / 6$ was superior significantly upon the rest other date in the average of 100 seed weight $(3.89 \mathrm{~g})$ witha percentage increase of $9.27 \%$ compared tothe firstdate $15 / 5$, which gave lessweight(3.55g). On the other hand, thirddatewassuperior uponthe first datesignificantly.Allspraying treatments had a significant effect compared to control. Sprayhumusandhighphosphorusfertilizer gave the highest valueof100 seed weight (3.81, and 3.78g, respectively) with a percentage increase of $9.8 \%$ and $8.9 \%$ comparedto control treatment. Theinteractionbetween planting dates and spraying treatmentshadsignificant effect on 100 seed weight, and the interaction between sprayinghighphosphorusfertilizer * second date $15 / 6$ was superior significantly (4.10) on theother interactions, whilecontrol treatments atallplanting datesgave lowervalues(ranging between $3.20-3.66 \mathrm{~g}$ ).

Table (5):Effect ofplanting dates, some stimuli spraying and their interactions on 100 seed weight (g)

\begin{tabular}{|c|l|l|l|l|l|l|}
\hline A & SA $0.5 \mathrm{mM}$ & SA $1 \mathrm{mM}$ & Humic acid & High P fert. & average \\
\hline $15 / 5$ & 3.55 & 3.55 & 3.27 & 3.67 & 3.87 & 3.56 \\
\hline $15 / 6$ & 3.66 & 3.93 & 3.93 & 3.84 & 4.10 & 3.89 \\
\hline $15 / 7$ & 3.20 & 3.82 & 3.76 & 3.93 & 3.83 & 3.71 \\
\hline $15 / 8$ & 3.45 & 3.73 & 3.69 & 3.41 & 3.30 & 3.61 \\
\hline average & 3.47 & 3.76 & 3.66 & 3.81 & 3.78 & \\
\hline LSD $_{0.05}$ & \multicolumn{6}{|l|}{$\mathrm{A}=0.1405 \mathrm{~B}=0.1455 \mathrm{AB}=0.2836$} \\
\hline
\end{tabular}

Table(6) showed that first dategavelessseed yield significantly compared to otherdates. Second date wassuperior upon other dates which gave $1315.8 \mathrm{~kg}_{\mathrm{gha}}{ }^{-1}$ with an increase of $25.6 \%$ compared to the firstdate. On the other hand, allsprayingtreatments had a significant increase compared to control. Sprayinghighphosphorusfertilizer was superior significantlycompares to other spraying treatments, and gave $1260 \mathrm{~kg} \cdot \mathrm{ha}^{-1}$. Spraying humic acid were superior also and gave $1228.6 \mathrm{~kg} \cdot \mathrm{ha}^{-1}$ compared tosalicylic acid $1 \mathrm{mM}$. The interaction had significant effect, and spraying ofhighphosphorus fertilizer * second datewas superior compared to other interactions which gave $1477 \mathrm{~kg}$.ha- ${ }^{-1}$, while control treatments at first date gaveless value $\left(763.9 \mathrm{~kg} \mathrm{ha}^{-1}\right)$.

Table (6):Effect ofplanting dates, some stimuli spraying and their interactions on seed yield $(\mathrm{k} \backslash \mathrm{g})$

\begin{tabular}{|r|r|r|r|r|r|r|}
\hline \multicolumn{1}{|r|}{} & \multicolumn{1}{|c|}{ control } & SA $0.5 \mathrm{mM}$ & \multicolumn{1}{c|}{ SA $1 \mathrm{mM}$} & Humic acid & High P fert. & \multicolumn{1}{c|}{ average } \\
\hline $15 / 5$ & & & & & & \\
\hline $15 / 6$ & 763.9 & 856.0 & 913.2 & 1044.2 & 995.3 & 914.5 \\
\hline $15 / 7$ & 1141.9 & 1403.9 & 1158.0 & 1398.1 & 1477.0 & 1315.8 \\
\hline $15 / 8$ & 993.7 & 1261.7 & 1175.4 & 1213.9 & 1194.6 & 1167.9 \\
\hline average & 1057.4 & 1238.2 & 1374.1 & 1258.1 & 1373,0 & 1260.2 \\
\hline LSD $_{0.05}$ & 989.2 & 1190.0 & 1155.2 & 1228.6 & 1260.0 & \\
\hline
\end{tabular}

Table(7) showed that second date 15/6 was superior compared to the other dates in the proportion ofprotein $(21.58 \%)$ with an increase of5.3\%compared tothe thirddate, which gave the lowest averagepercentage ofprotein $(20.49 \%)$. The table also showed that salicylic acid treatments had no significant effectonthe proportion ofprotein,but tendto increase, while spraying highphosphorusfertilizerandhumic acid increasedit significantly(22.93and21.16\%) comparedto control treatment. Theinteractionbetween treatments hadsignificant effectas spraying high phosphorus fertilizerinthe third date $15 / 7$ was superior (23.15\%), while the controltreatmentat firstdate gave lessvalue(18.46).

Table (7):Effect ofplanting dates, some stimuli spraying and their interactions on protein content \%

\begin{tabular}{|c|l|l|l|l|l|c|}
\hline & Control & SA $0.5 \mathrm{mM}$ & SA $1 \mathrm{mM}$ & Humic acid & High P fert. & average \\
\hline $15 / 5$ & 18.46 & 22.39 & 19.74 & 19.03 & 23.37 & 20.60 \\
\hline $15 / 6$ & 20.15 & 20.52 & 22.59 & 21.93 & 22.71 & 21.58 \\
\hline $15 / 7$ & 19.98 & 19.21 & 20.64 & 22.46 & 23.15 & 20.49 \\
\hline $15 / 8$ & 20.35 & 19.85 & 18.75 & 21.21 & 22.48 & 20.53 \\
\hline average & 19.74 & 20.49 & 20.43 & 21.16 & 22.93 & \\
\hline LSD $_{0.05}$ & \multicolumn{7}{|c|}{$\mathrm{A}=0.820 \mathrm{~B}=0.860$} \\
\hline
\end{tabular}


Notes fromthe results of tables (2-7) showed that second datewas superior significantly inpods number.plant ${ }^{-1}, 100$ seed weightand dry seed yield. It wasattributedto increase the production ofdry matterat physiological maturitystage as a result ofthe length ofgrowth period, which led to increasephotosynthetic efficiencyandreadiness oftheir productstransferred to thestem and leavesthereby increasingtheir contribution to thefood processingplant[5]. These resultsare consistent with[6, 7]. It is notedfrom the results of table $(3,4)$ outweigh thefourthdate significantly innumber of seeds.pod ${ }^{-1}$ and pod length,whichattributedto the exposure ofplantstofavorable environmental conditionsthatencouragedto increasephotosynthesisand thus increasefood processing[5].These resultsare consistent with the results of $[8,9]$.

Spraying highphosphorusfertilizerwas superior significantly in pods number.plant ${ }^{-1}$, pod length, 100 seed weightanddry seed yield (table $2,4,5,6$ ). It wasattributedtothe impact ofphosphate fertilizerin improving plant growthandthereby increase podsyield [10].The increasehappeningwhensprayinghighphosphorus fertilizerreturns toits role in thetransfer of materialsmanufacturedfrom leafs toseedformed[11], in addition to the role ofphosphorusin the synthesis ofnucleic acidswhich is importantin theprocess of proteins formation [12]. This wasconsistent withthe findings of [13, 14 and15]. Thesuperiority ofhumic acidsprayinginmost of thetraitsattributed tothe role oforganic matterin increasingthe shoot, which increases the amount ofobjectionto thelightand thenan increase in photosynthesis processand materialsmanufacturedin the leafs, which led to increasing the number ofseeds.pod ${ }^{-1}$ and increase 100-seed weightand thereforereflectedin high yield, as well as its role inincreasing thepermeability ofcell membranes, which facilitates and acceleratestheabsorption ofnutrientsandincrease the proportion ofprotein[16]. Thiswas consistentwiththe results of[17 and 18].

\section{References}

[1]. Anjum, M.S. , Z. I. Ahmed, and C. A. Rauf, 2006. "Effect of Rhizobium inoculation and nitrogen fertilizer on yield and yield components of mungbean," Int. J. Agric. and Biol., 8( 2) : 238-240.

[2]. El-Shraiy, A. M.and Hegazi, A. M. 2009. Effect of acetylsalicylic acid, indole-3- butyric acid and gibberellic acid on plant growth and yield of pea (PisumsativumL.). Aust. J. Bas. Appl. Sci., 3(4): 3514-3523.

[3]. Chen, Y. and Aviad T. (1990). Effects of humic substance on plant growth. In McCarthy, CE Clapp, RL Malcolm, PR Bloom (eds.). Humic substances in soil and crop sciences. Soil Sci. Soc.Amer. pp.161-186.

[4]. Tan, K. H. (2003). Humic Matter in Soil Environment, Principles and Controversies, Marcel Dekker, Inc. 270 Madison Avenue, New York.

[5]. Aochalm, S.N. 2006. Growth, yield and quality of different genotypesfrom rapeseed bythe effect ofplanting date. PhD thesis. Faculty of Agriculture. University of Baghdad/Iraq.

[6]. Rabbani ,M.G., A.K.M.S.H. Chowdhury, M.A. Bari and M.A. Salam. 2013. Effect of variety and sowing date on the growth and yield of summer mung bean (VignaradiataL. Wilczek). J. Agrofor. Environ. 7 (1): 27-30, 2013.

[7]. Ali ,S. ; T. Khaliq; A. Ahmad1; M. Rehman1, S. Hussain; K. Rehman and M. Wajid . 2014 . Genotypic variations in mungbean yield and its attributes in response to different sowing times. Res. J. Agric. and Environ. Manage., 3(5): 255-258.

[8]. Sarkar, M. A. R., M. H. Kabir, M. Begum and M. A. Salam. 2004. Yield performance of mung bean as affected by planting date, varietyand plant density. J. Agro., 3(1): 18-24.

[9]. Harunor, R.M.; M.S. Aktar; I. Hossain; M.M. Rahmam; M.R. Hasnat and R.M. Nair .2013. Effect of dates of sowing on incidence and severity of mungbeanyellow mosaic virus and cercosporaleaf spot of mung bean. Int. J. Adv. Res. \& Tech., 2(9): 2278-7763.

[10]. Badr, M.M.; S.A.A. Bassal and E.M. Ibrahim. 2003. Effect of preceding winter crops, nitrogen and phosphorous fertilizer levels on growth and yield of maize (Zea mays L.). J. Agric. Sci. Mansoura Univ., 28(9): 6591-6601.

[11]. Peng Z, Li C (2005) Transport and partitioning of phosphorus in wheat as affected by P withdrawal during flag-leaf expansion. Plant and Soil , 268, 1-11.

[12]. Gad, N. ; M.R. Abdel-Moez and H. Kandil (2012). Influence of cobalt and mycrorrhizae mediated phosphorus on some higher plants growth and yield. J. Basic. Appl. Sci. Res., 2(11):11942- 11951.

[13]. Shafeek, M.R., F.S. Abdel-Al and A.H. Ali, 2004. The productivity of broad bean plant as affected by chemical and or natural phosphorus with different bio fertilizer. J. Agric. Sci. Mansoura Univ., 29: 2727-2740.

[14]. Beheidi, M.A., A.A. El-Mansi , E.A. El-Ghamriny , F.F. Mohamed , and M. M.Ramadan .2005. Effect of mineral and biofertilizers on growth ,yield and quality of pea plants under sandy soil conditions .Zagazig J. Agric. Res., 32(5): 1453-1473.

[15]. Hashemabadi, D. 2013. Phosphorus fertilizers effect on the yield and yield components of faba bean (Viciafaba L.). Ann. Bio. Res., 4 (2):181-184

[16]. Esmaeilian, Y.; A.R. Sirousmehr and M.R. Asghripour. 2012. Comparison of sole and combined nutrient application on yield and biochemical composition of sunflower under water stress . J. Appl. Sci. and Tech.,2(3):50-62.

[17]. Anju. S and A. Vijayalakshmi .2013.Residual effect of integrated nutrient management with farmyard manure , coir pith and press mud compost on cluster bean. I. J. S. N., Vol., 4(3):405-407.

[18]. Hak, S.H. Gad, A.M. Ahmed, Y.M.M. Moustafa. 2012. Effect of foliar application with two antioxidants and humic acid on growth, yieldand yield components of peas (PisumsativumL). 